\title{
USE OF THERMAL ANALYSIS FOR THE DETECTION OF CALCIUM OXALATE IN SELECTED FORMS OF PLASTERING EXPOSED TO THE EFFECTS OF SERPULA LACRYMANS
}

\author{
Drahomíra Cígler Žofková ${ }^{a, *}$, JiŘí FrankL ${ }^{b}$, Dita Frankeová ${ }^{b}$ \\ ${ }^{a}$ Czech Technical University in Prague, Faculty of Civil Engineering, Thákurova 7, 166 29 Prague 6, Czech \\ Republic \\ ${ }^{b}$ Czech Academy of Sciences, Institute of Theoretical and Applied Mechanics, Prosecká 809/76, 19000 Prague 9, \\ Czech Republic \\ * corresponding author: drahomira.zofkova@post.cz
}

\begin{abstract}
The article discusses the interaction of metabolic products of a wood-destroying fungus of the dry rot species (Serpula lacrymans (Wulfen) P. Karst.) with a commonly used lime mortar. Mortar samples used in the presented experiment were made mostly in laboratory conditions so as to make it possible to set input conditions and to determine initial properties of the examined samples. Matured lime mortar samples were placed in cultivation boxes with a growth of Serpula lacrymans and exposed to its action for a predetermined period of time. For a comparison, mortar samples taken "in situ" from real structures were also subjected to the experiment. The examined samples were subjected to a thermal analysis and a comparative measurement by infrared spectroscopy (FTIR). The results of the measurement of infected samples were compared with the results obtained in the reference (control) samples. The experiment carried out was focused on assessing the presence of calcium oxalate, which is secreted into the surroundings of the mycelium during the active growing of Serpula lacrymans.
\end{abstract}

KEYwORDS: Dry rot, Serpula lacrymans, lime mortar, thermal analysis, infrared spectroscopy (FTIR), calcium oxalate.

\section{INTRODUCTION}

Our working group focused on acquiring new knowledge in the field of detecting calcium oxalate in the activity of Serpula lacrymans when in contact with lime mortars, i.e., building materials containing calcium $\mathrm{Ca}^{2+}$, which is typical of Czech buildings.

Serpula lacrymans is one of the brown rot fungi whose activities cause significant material and financial losses in the order of millions of dollars a year in many countries around the world [1. This fungus is the most common saprophyte and is considered to be the most destructive and least controllable internal wood-destroying fungus especially due to its ability to transport water and nutrients over long distances. The basic abiotic factors that affect the growth of Serpula lacrymans include optimal temperature in the range of $21-25^{\circ} \mathrm{C}, \mathrm{pH}$ value in the range of acidic to neutral (optimally in the range of 4-5), limited air movement, a culture water potential of not less than $-6 \mathrm{MPa}$, content moisture in the wood around $20 \%$ [2, 3] and probably also a source of a divalent ion such as calcium [1]. Among the characteristics of the organism that rank Serpula lacrymans at the top of the list of the most common wood-destroying fungi in buildings [4] is the highly efficient transport system that transports water, nitrogen, iron, calcium, etc., through rhizomorphs and an efficient solubilization system. This allows the extraction of metal ions (especially $\mathrm{Fe}^{2+}$ and $\mathrm{Ca}^{2+}$ ) from plaster and stone around the mycelium [5, which the fungus then uses to its advantage [6] 8 . During its growth, Serpula lacrymans regulates the $\mathrm{pH}$ of the substrate during its own metabolic processes while oxalic acid $\left(\mathrm{C}_{2} \mathrm{O}_{4} \mathrm{H}_{2}\right)$ is formed as a metabolic product [6, 9], which has an effect on the decomposition of wood [10]. The issue of oxalic acid in wood-destroying fungi and its influence on the modification of the microenvironment is extensively discussed in several specialist publications [10 13.

\section{AIMS}

The presented study focuses on the issues of processes taking place in mortars that are in contact with Serpula lacrymans. The objective is to monitor changes and evaluate the use of the method of thermal analysis in assessing the formation of calcium oxalate in lime mortars exposed to the effects of Serpula lacrymans. A thermal analysis is a method commonly used in the evaluation of building materials (e.g., the carbonation of concrete [14], ceramic and glass raw materials [15], low-fired ceramics [16]) and was also used in the evaluation of the patina formed on the surface of dolomitic rocks used in the construction of a Romanesque church in Spain [17].

Calcium oxalate is the most commonly found oxalate. Its occurrence is usually associated with the activity of fungi in both natural and building environments. In living organisms and the environment, the 
main forms are monohydrate (whewellite) and dihydrate (weddellite). The solubility of calcium oxalate increases at $\mathrm{pH}<5$. Its production can be influenced by many factors (e.g., the carbon and nitrogen source, $\mathrm{pH}$ of the environment, etc. [18]), which contribute to the biological deterioration of the properties of rock and mineral substrates, lignocellulosic materials and, indirectly, to the change and loss of elements (or traces) of cultural heritage [11. Oxalate can be potentially toxic and must therefore be eliminated or separated from the cells of the organism. Oxalate detoxification can be performed by means of degradation, which is a common property of wood-destroying fungi 19. Oxalate detection can be evaluated during surveys of constructions as an indicator of the activity of living organisms. This study also focuses on this fact.

\section{MATERIALS AND METHODS}

\subsection{ORGANISMS}

Within the research activity, a pure form of Serpula lacrymans culture was used, which was prepared by inoculation in the laboratory of the biological degradation of material of the Institute of Theoretical and Applied Mechanics of the CAS, v. v. i. In the samples taken from a structure, the culture of the wood-destroying fungus was determined after staining it with $\mathrm{AgNO}_{3}$ solution on a Versamet Union 9666 epifluorescence microscope (Japan). The identification was performed by a comparison with keys [20] and [21].

\subsection{Culture medium And CONDitions}

Culture vessels with a surface area of $210 \times 140 \mathrm{~mm}$ and a height of $60 \mathrm{~mm}$ were prepared in which the test mortar bodies were exposed to the activity of the wood-destroying fungus. A $10 \mathrm{~mm}$ layer of Malt Extract Agar Base gel (w/Mycological Peptone - HiMedia Laboratories Pvt. Ltd.) was prepared at the bottom of sterile boxes and a pure Serpula lacrymans culture was inoculated onto it. The culture vessels were placed in a climatic chamber with stable conditions at a temperature of $23.5 \pm 2.5^{\circ} \mathrm{C}$ and a relative humidity of $65 \pm 5 \%$. They were left there for 14 days. During this time, the growth of the Serpula lacrymans mycelium covered the entire bottom of the culture vessels with a continuous layer.

\subsection{MORTAR TEST SPECIMENS}

A lime mortar consisting of lime putty and aggregate in a ratio of 1:3 was chosen for the production of test specimens [22]. Lime putty was made from AQUA LIME PUTTY burnt lime (produced by AQUA obnova staveb s.r.o.), aggregate (fraction $0 / 4 \mathrm{~mm}$ ) from the Straškov locality and lukewarm drinking water from the water supply system. The test specimens were produced at room temperature with a size of $20 \times 20 \times 100 \mathrm{~mm}$ while making tests and complying with the requirements for fresh mortars pursuant to the prescribed ČSN EN 1015-3,7 standards as amended. The specimens were stored for 6 days in a moist environment (in a polyethylene bag), then removed from their moulds and a day later transferred to an air-conditioned room at $20 \pm 3^{\circ} \mathrm{C}$ and $60 \pm 5 \%$ relative humidity where they remained for 30 days.

After the mortar samples were collected from the building, they were stored in closeable microtene bags and stored in their original condition in a cooling box at a temperature of $15^{\circ} \mathrm{C}$ until laboratory measurements were performed.

\subsection{VERIFICATION OF CALCIUM OXALATE CAO CRYSTALS PRODUCTION BY MEANS OF THERMAL ANALYSIS}

For our study, we used the thermogravimetric (TG) analysis. During the heating of the measured specimens, the change in weight was continuously recorded as a function of the rising temperature 23] on the SDT Q600 instrument produced by TA INSTRUMENTS in the temperature range of $25-1000{ }^{\circ} \mathrm{C}$. For the purposes of the analyses, $20-30 \mathrm{mg}$ of a sieved mortar sample was weighed out into ceramic crucibles using a standardized sieve of $0.063 \mathrm{~mm}$ in order to separate the aggregate from the binder and to refine the results. The thermal decomposition was performed in a nitrogen atmosphere at a heating rate of $20^{\circ} \mathrm{C}$ per minute for all measurements.

\subsection{INFRARED SPECTROSCOPY (FTIR)}

The spread test samples of mortars used in the above thermal analyses were further analysed on the iZ10 sub-module of the iN10 infrared microscope (Thermo Scientific). They were measured using a transmission technique in a $\mathrm{KBr}$ tablet in the range of $4000-400 \mathrm{~cm}^{-1}$ with a spectral resolution of $4 \mathrm{~cm}^{-1}$.

\section{Results AND Discussion}

Within the study, samples of a laboratory-prepared lime mortar exposed to Serpula lacrymans were tested under optimal conditions for its growth. Samples of mortars taken "in situ" from a real building, where, at the place of sampling, the presence of Serpula lacrymans had been recorded on a long-term basis, were also subjected to thermal analyses. The results of the analyses of samples of lime mortars damaged by the activity of the wood-destroying fungus were compared with samples that underwent the same temperature and humidity conditions but which, however, were not in contact with Serpula lacrymans. This is a control measurement (so-called zero control).

The comparative measurement was performed by means of the decomposition of calcium oxalate with the general formula $\mathrm{CaC}_{2} \mathrm{O}_{4}$, the output of which is shown in Figure 1. Calcium oxalate is the result of 


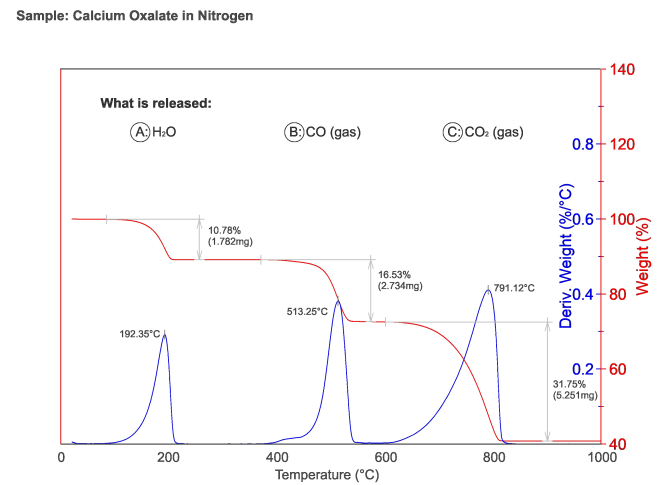

Figure 1. TG/DTG curves of calcium oxalate $\mathrm{CaC}_{2} \mathrm{O}_{4}$.

the reaction of oxalic acid $\left(\mathrm{C}_{2} \mathrm{H}_{2} \mathrm{O}_{4}\right)$ with a calciumcontaining material. In our study, the source of this element is lime plastering.

Both the TG and DTG curves recorded in Figure 1 show the thermal decomposition of the whewellite mineral in three partial steps (1, 2, 3n that are separated from each other by plateaus. These plateaus correspond to thermally stable phases. The thermal decomposition begins at $100^{\circ} \mathrm{C}$. From this point, the dehydration of $\mathrm{CaC}_{2} \mathrm{O}_{4} \cdot \mathrm{H}_{2} \mathrm{O}$ begins; crystal water is released. This phase is completed at $205^{\circ} \mathrm{C}$. In the following section, up to a temperature of $380^{\circ} \mathrm{C}$, the formed anhydrous $\mathrm{CaC}_{2} \mathrm{O}_{4}$ is thermally stable. Between 380 and $545^{\circ} \mathrm{C}$, CO is then released while $\mathrm{CaCO}_{3}$ is formed. Up to a temperature of $605^{\circ} \mathrm{C}$, the calcium carbonate formed is thermally stable. Beyond this point, its thermal decomposition to calcium oxide takes place and carbon dioxide is released. The decomposition is completed at $825^{\circ} \mathrm{C}$. The individual decomposition steps are described stoichiometrically by the equations below.

$$
\begin{gathered}
\mathrm{CaC}_{2} \mathrm{O}_{4} \cdot \mathrm{H}_{2} \mathrm{O} \rightarrow \mathrm{CaC}_{2} \mathrm{O}_{4}+\mathrm{H}_{2} \mathrm{O} \\
\mathrm{CaC}_{2} \mathrm{O}_{4} \longrightarrow \mathrm{CaCO}_{3}+\mathrm{CO} \\
\mathrm{CaCO}_{3} \longrightarrow \mathrm{CaO}+\mathrm{CO}_{2}
\end{gathered}
$$

From the test beams of the lime mortars (marked SD1) produced in the laboratory, the surface of which was overgrown with mycelium of Serpula lacrymans for 56 days, the mycelium was mechanically cleaned before sampling of the mortar sample and sampling was performed from the surface of the tested specimens. Spread-out mortar samples (without aggregate) weighing $21 \mathrm{mg}$ were placed in the ceramic crucibles of the TA instrument. The output of the measurement is recorded in Figure 2, in which three peaks corresponding to the temperature range for the decomposition of calcium oxalate are visible. The most significant interval corresponds to the thermal decomposition of $\mathrm{CaCO}_{3}$ in the range of $600-870{ }^{\circ} \mathrm{C}$.

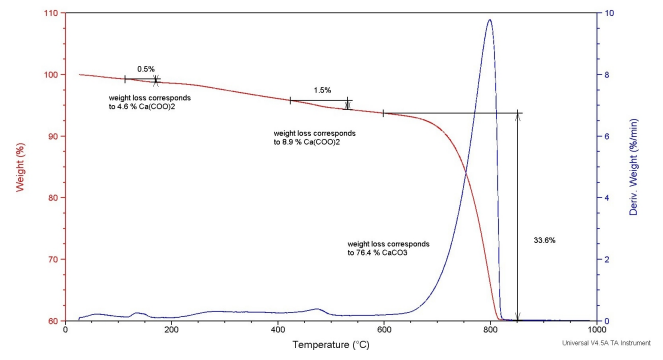

Figure 2. TG DTG curve of sample SD1.

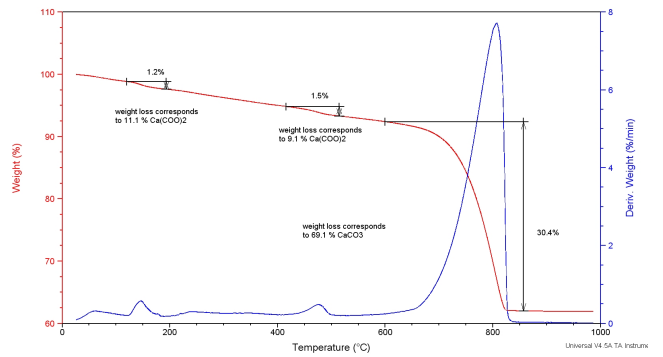

Figure 3. TG DTG curve of sample Hrádek nad Ohř́i.

Thermal measurements that followed were performed on mortar samples taken as part of a construction and technical survey of a structure in Hrádek nad Ohř́, where they had been exposed to the long-term effects of Serpula lacrymans activity. The mortar samples from the actual structure were treated similarly to the above-mentioned laboratory-prepared and damaged samples. A ground plaster sample weighing $27 \mathrm{mg}$ was taken from the surface part, from which the Serpula lacrymans mycelium had been mechanically removed with a brush, and weighed into ceramic crucibles. Three areas corresponding to the calcium oxalate degradation peaks are visible in the measurement outputs, see Figure 3. In the first phase, water is released, in the second phase, $\mathrm{CO}$ is released, and the peak for the decomposition of $\mathrm{CaCO}_{3}$ is again the most marked.

On the thermal analysis record (Figure 3), the results correspond to an approximate content of $10 \%$ $\mathrm{CaC}_{2} \mathrm{O}_{4}$ in the measured sample (i.e., in the sieved fraction). The proportion of calcium carbonate formed by the transformation of calcium oxalate cannot be quantified, because it partly belongs to the decomposition of $\mathrm{CaCO}_{3}$ contained in the plaster.

The temperature interval of the calcium carbonate decomposition is slightly shifted in the experimental measurements of the thermal analysis as compared to the temperature range in the decomposition of the comparative measurement of calcium oxalate. This is probably related to the crystallization modification of $\mathrm{CaCO}_{3}$ 24.

Control measurements were made on the lime plaster samples produced in the laboratory (marked R1). The spread sieved samples weighing $23 \mathrm{mg}$ were placed in ceramic cups of the thermal analysis apparatus and heated up to $1000{ }^{\circ} \mathrm{C}$. The output of the measurement is shown in Figure 4 and corresponds to the course 


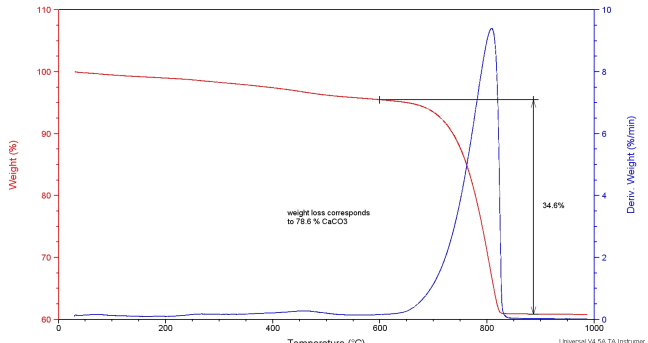

Figure 4. TG/DTG curve of sample R1 (control).

of the thermal decomposition of a lime binder (plaster). At the beginning, the measured samples are gradually dehydrated and, in the temperature range of approximately $604-860{ }^{\circ} \mathrm{C}$, a single distinct band of decomposition of $\mathrm{CaCO}_{3}$ is recorded.

The above samples (SD1, Hrádek nad Ohř́, R1) were independently subjected to a comparative measurement by the FTIR method. The laboratoryproduced plaster samples overgrown with Serpula lacrymans (SD1) and plaster samples from the structure (Hrádek nad Ohří) showed a similar course of spectra as the plaster samples without the activity of the biodeteriogen (R1) (see Figure $5 \mathrm{a}, \mathrm{b}, \mathrm{c}$ ). The dominant features of the measured samples' spectra were bands extending from 1350 to $1550 \mathrm{~cm}^{-1}$ and also bands of vibrations $875 \mathrm{~cm}^{-1}$ and $1800 \mathrm{~cm}^{-1}$. The outputs were compared with the stored library spectra of $\mathrm{CaCO}_{3}$, shown in Figure 5 (d), and $\mathrm{SiO}_{2}$, the content of which in the measured samples was expected. In the case of mortar samples from Hrádek nad Ohř́, bands that correspond to the presence of calcium oxalate were recorded $\left(\sim 1630 \mathrm{~cm}^{-1}, 1320\right.$ $\mathrm{cm}^{-1}$ and a weak band of $\sim 780 \mathrm{~cm}^{-1}$ ), whose library spectra in a pure form are shown in 5 (e). The outputs of the FTIR measurement indicate the effect of the period of time during which the measured sample was exposed to the activity of the biodeteriogen. For this method of measurement, the time period of 56 days, during which the mortar sample was exposed to the activity of Serpula lacrymans, was insufficient and this exposure did not have a significant effect on the results as compared to the outputs in the plaster samples taken from the structure.

\section{Conclusions}

As a part of the research, we used thermal analysis and infrared spectroscopy (FTIR) techniques. Samples of lime mortars produced in the laboratory and, for a comparison, mortars taken "in situ" from a real structure were also subjected to these two analyses.

The initial experiment using the thermal analysis was focused on mortar samples with various forms of surface damage caused by Serpula lacrymans activity. Figures 2/344 indicate slight changes in the decomposition of the mortars observed in the thermal measurements. The data obtained indicate changes in the composition of the mortar samples in the absence

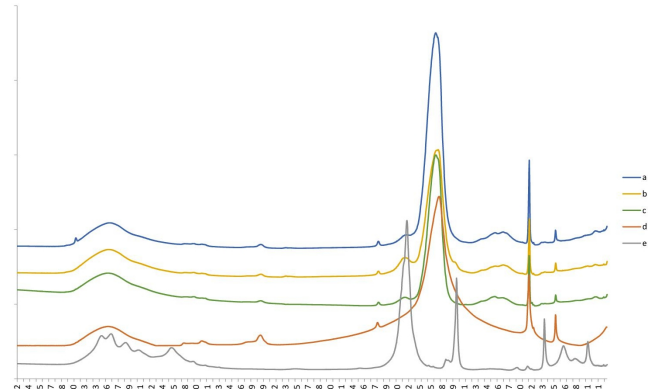

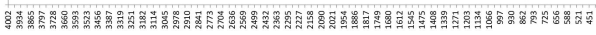

Figure 5. FTIR - spectrum of the sample SD1 (a), Hrádek nad Ohří (b), R1 (c), $\mathrm{CaCO}_{3}$ (d), $\mathrm{CaC}_{2} \mathrm{O}_{4}$ (e).

of the wood-destroying fungus (R1) and when there is an activity of Serpula lacrymans on the surface of the test specimens (SD1). However, it is not entirely clear from the performed measurements to what extent the presence of $\mathrm{CaC}_{2} \mathrm{O}_{4}$ is caused exclusively by the influence of metabolic changes during the active growth of Serpula lacrymans.

The most pronounced bands (peaks) in the thermal analysis, corresponding to the first and second stages of calcium oxalate decomposition, were recorded in mortar samples exposed to the activity of Serpula lacrymans. This phenomenon showed most markedly in the case of the mortar sample taken from the structure where the activity of the wood-destroying fungus was long-lasting. The bands (peaks) corresponding to the decomposition of $\mathrm{CaCO}_{3}$ are of a similar intensity for all tested mortar samples and are recorded in the same temperature range. For the weight losses caused by the release of $\mathrm{CO}_{2}$ from $\mathrm{CaCO}_{3}$, as shown in the individual graphs $\left(\Delta \mathrm{m}_{C}=34.6 \% ; 33.6 \%\right.$ and $30.4 \%$ ), it is not possible to exactly determine the part of carbon dioxide originating from the decomposition of calcium carbonate from the binder of the mortar and the part originating from the decomposition of calcium oxalate produced by Serpula lacrymans.

The conclusions of the performed FTIR measurements correspond to the results of the thermal analysis for all measured sets. The most prominent bands of calcium oxalate were shown in mortar samples taken from the structure where the activity of Serpula lacrymans was long-lasting.

\section{ACKNOWLEDGEMENTS}

We thank our collaborator Petra Mácová from the Centre of Excellence Telč (CET) of the Czech Academy of Sciences, v. v. i., who performed infrared spectroscopy (FTIR) measurements and thus contributed to our research.

The results mentioned in the article were obtained with the support of the SGS19/144/OHK1/3T/11 grant and were also financially supported by the Czech Academy of Sciences under the framework Strategy AV21, Research program 23: "City as a Laboratory of Change; Construction, Historical Heritage and Place for Safe and Quality Life". 


\section{REFERENCES}

[1] J. W. Palfreyman, N. A. White, T. E. J. Buultjens, H. Glancy. The impact of current research on the treatment of infestations by the dry rot fungus Serpula lacrymans. International Biodeterioration $\mathcal{E}$ Biodegradation 35(4):369-395, 1995. https://doi.org/10.1016/0964-8305(95)00064-3.

[2] O. Schmidt. Wood and Tree Fungi - Biology, Damage, Protection, and Use. Springer, Berlin, 2006. https://doi.org/10.1007/3-540-32139-x.

[3] D. H. Jennings, A. F. Bravery. Serpula Lacrymans: Fundamental Biology and Control Strategies. Wiley, Chichester, 1991. ISBN 047193058X.

[4] J. Gabriel, K. Švec. Occurrence of indoor wood decay basidiomycetes in Europe. Fungal Biology Reviews 31(4):212-217, 2017. https://doi.org/10.1016/j.fbr.2017.05.002.

[5] J. W. Palfreyman. The domestic dry rot fungus, Serpula lacrymans, its natural origins and biological control. In Workshop ARIADNE 8 - Bio-degradation of cultural heritage, ARCCHIP. 2001.

[6] J. Bech-Andersen. The Dry Rot Fungus and Other Fungi in Houses. 5th edition. Hussvamp laboratoriet, Denmark, 1995. ISBN 87-89560-25-6. IRG/WP 95-10124.

[7] J. Bech-Andersen. The influence of the dry rot fungus (Serpula lacrymans) in vivo on insulation materials. Material und Organismen 22:191-202, 1987.

[8] J. Bech-Andersen. Serpula lacrymans the dry rot fungus: review of previous papers, 1989. International Research Group on Wood Preservation Document IRG/WP/1393.

[9] J. W. Palfreyman, E. M. Philips, H. J. Staines. The effect of calcium ion concentration on the growth and decay capacity of Serpula lacrymans and Coniophora puteana. Holzforschung 50:3-8, 1996. https://doi.org/10.1515/hfsg.1996.50.1.3

[10] J. S. Schilling, J. Jellison. Oxalate regulation by two brown rot fungi decaying oxalate-amended and non-amended wood. Holzforschung 59:681-688, 2005. https://doi.org/10.1515/hf.2005.109

[11] G. M. Gadd, J. Bahri-Esfahani, Q. Li, et al. Oxalate production by fungi: significance in geomycology, biodeterioration and bioremediation. Fungal Biology Reviews 28(2-3):36-55, 2014. https://doi.org/10.1016/j.fbr.2014.05.001.
[12] F. Green, M. J. Larsen, J. E. Winandy, T. L. Highley. Role of oxalic acid in incipient brown-rot decay. Material und Organismen 26(3):191-213, 1991.

[13] M. Guggiari, R. Bloque, M. Arango, et al. Experimental calcium-oxalate crystal production and dissolution by selected wood-rot fungi. International Biodeterioration \& Biodegradation 65(6):803-809, 2011. https://doi.org/10.1016/j.ibiod.2011.02.012

[14] P. Mec, T. Murínová, K. Kubečka. Možnosti využití termické analýzy v oblasti stavebních materiálů. Stavebni obzor (2):39-43, 2013.

[15] Termická analýza keramických a sklářských surovin, learning text, 2012. ICT in Prague, Prague.

[16] Termická analýza a mikrostruktura nízkopálené keramiky, learning text, 2012. ICT in Prague, Prague.

[17] J. L. Perez-Rodriguez, A. Duran, M. A. Centeno, et al. Thermal analysis of monument patina containing hydrated calcium oxalate. Thermochimica Acta 512(1-2):5-12, 2011. https://doi.org/10.1016/j.tca.2010.08.015.

[18] Y. Akamatsu, M. Takahashi, M. Shimada. Production of oxalic acid by wood-rotting basidiomycetes grown on low and high nitrogen culture media. Material und Organismen 28(4):251-264, 1994.

[19] T. Watanabe, N. Shitan, S. Suzuki, et al. Oxalate efflux transporter from the brown rot fungus Fomitopsis palustris. Applied and Environmental Microbiology 76(23):7683-7690, 2010. https://doi.org/10.1128/aem.00829-10

[20] K. M. Nobles. Identification of cultures of wood inhabiting hymenomycetes. Canadian Journal of Botany 43(9):1097-1138, 1965. https://doi.org/10.1139/b65-126

[21] T. Huckfeldt, O. Schmidt. Identification key for European strand-forming house-rot fung. Mycologist 20(2):42-56, 2006. https://doi.org/10.1016/j.mycol.2006.03.012

[22] O. Severin. Stavba domu v praxi. Díl II. Grada Publishing, Praha, 2002. ISBN 80-247-0263-0.

[23] A. Blažek. Termická analýza. SNTL - Nakladatelství technické literatury, Praha, 1974.

[24] Uhličitan vápenatý. [2020-06-13], https://cs.wikipedia.org/wiki/Uhli\%C4\%8Ditan_v\% C3\%A1penat $\%$ C3\%BD 